\title{
Teacher Professionalism: Analysis of Professionalism Phases
}

\author{
Cipto Wardoyo ${ }^{1}$, Aulia Herdiani ${ }^{1} \&$ Sulikah $^{1}$ \\ ${ }^{1}$ Faculty of Economics, Universitas Negeri Malang, East Java, Indonesia \\ Correspondence: Aulia Herdiani, Faculty of Economics, Universitas Negeri Malang, East Java, Indonesia. Tel: \\ 62-81-295-259-459. E-mail: aulia.herdiani.fe@um.ac.id
}

Received: September 27, 2016

doi:10.5539/ies.v10n4p90
Accepted: November 2, $2016 \quad$ Online Published: March 30, 2017

URL: https://doi.org/10.5539/ies.v10n4p90

\begin{abstract}
Teacher professionalism has become a distinctive concern in educational discussions. Based on Teacher and Lecturer Act No.14 2005 carried out by Indonesian Government, teacher professionalism, considered as an assessment aspect of teacher quality, could be drawn by four competences, pedagogical competence, personal, competence, social competence, and professional competence. Hargreaves (2000) captured and fragmented the pattern of professionalism development through four phases. This study, a perception study, observed 100 teachers to draw the pattern of teacher professionalism, particularly in Tulungagung and Blitar District, East-Java, Indonesia based on Hargreaves professionalism phases. The results of this study identify that the likelihood phase of teacher professionalism in Indonesia is in collegial phase. Additionally, the criteria of professionalism enhancement reflect the professionalism development based on professionalism ages by Hargreaves (2000). Further, we observe the likelihood of professionalization become an influential factor of professionalism development. The results indicate that every phase captured the right pattern of professionalism development.
\end{abstract}

Keywords: pre-professional phases, autonomous professional phase, collegial professional phase, post-professional phase, teacher professionalism

\section{Introduction}

The professionalism of teachers has been observed extensively as one of the main issues in education. Teacher professionalism has been improved time to time along the growing of needs in education and it has been challenging the government and educators to put all on the show. The government has always answered it by carrying on and improving policies in education. It is proven by the issuance of No.14 Act 2005 about teachers and lecturers by Indonesian Government that particularly focuses on the improvement of teacher professionalism. Further, teacher professionalism is determined as the competences that meet professional education standards so that a teacher is required to possess a qualified professional background and to obtain the consequences as professionalization principles. These competences include of 1) pedagogical competence, 2) personal competence, 3) social competence, and 4) professional competence.

Teacher competences are related to how good teachers fulfill their roles as an educator, including how well prepared teachers in the class is until the evaluation needs to be done, how much the credits teachers need to handle, and how long the process will last properly (Dessler, 2009). These criteria define the performance of teachers when teachers are being assessed based on the tasks accomplished within an exact period. Teacher performance is determined by individual factors (i.e. willing, interest, motivation, characteristics, and individual perceptions) and institutional factors (i.e. duties and functional position, working climate, leadership styles, career paths, compensation or reward, and colleagues) related to an innovation achieved when a teacher has accomplished his/her duties based on the quality, quantity, and time required.

Teacher professionalism is the way what teachers think about their profession, why they should be professional, and how they behave and implement their knowledge and skills in which related to their profession. Many studies have discovered that the improving of professionalism will drive the boost of rewards (professionalization) that teachers will gain appropriately. In addition, it should virtually complement, since when teachers put many efforts in improving their teaching quality, they need a motivation instead. Otherwise, they might not even think to improve their qualifications as long as they could deliver what they have possessed to the students. Nonetheless, some studies in related issues reported different findings that professionalism and professionalization are substitutes. However, the difference of these findings is still being argued and observed in 
advance.

Educational policies of one country and its evolution might be different from others. It depends on the country people attributes, needs, and how capable they follow the change. Teachers might not improve their quality if there is no growing on student needs, however it will not be realized without any supports from the government. In other words, teacher professionalism has become urgency as a country level matter. The Indonesian government, particularly, has carried out legal provisions for teachers to improve their qualifications by holding professional training and other educational workshops. Besides, it is stated in educational acts and obligated that teachers have to level up their academic qualification in respect to the growing of student needs.

We often think about why teacher professionalism should be a concern of government. To answer this question, we need to look back to the earliest time of the formal education begun. Initially, an education system was not organized and developed well. All the things that educators needed to do were delivering the knowledge and skills they possessed without considering any attributes that might be related (Cuban, 1984; Curtis, 1988). Therefore, the concept of teacher professionalism is virtually and timely different. Hargreaves (2000) has conceptualized the different concept of teacher professionalism and its improvement within four ages, from pre-professional era to post-professional era in Anglophone cultures countries.

During pre-professional phase, the education system was simply considered as an intermediary to deliver historical knowledge. Therefore, someone only needed to be teaching assistant (pre-service education) to be a teacher. Pre-service education was practically helping prospective teachers to understand primary roles of a teacher in affective based teaching, interpersonal skills, and knowledge, yet it was not to replace theoretical competence (Fajet et al., 2005; Smith \& Lev-Ari, 2006; Cornu \& Ewing, 2008). Pre-professional phase was entirely different from autonomous professional phase which was indicated by the challenge of singularity on teaching and unquestionable traditions as the fundamental. Educational innovation was carried on and became the main concern on this phase. It was driven by investment in education linearly grown with educational needs of technology and knowledge (Olson, James, \& Lang, 1999; Hargreaves, 2000). Nonetheless, competences needed to boost innovation in education confined teacher singularity. Didactic and pedagogical curriculum changes could not be avoided and have been particular challenges for teachers (Olson, James, \& Lang, 1999). Considering how this change was being implemented, it included the concept of teacher professionalism.

Furthermore, teacher perception regarding professionalism was dramatically changed to professional development (Ifanti \& Fotopoulopou, 2011), which means that teachers were required to improve their quality linear to the growth of educational needs. Collegial or collaborative works among teachers in professional development have been an effective way to answer the challenge of curriculum change. Moreover, it has been a firm motivation to support learning process and professional improvement of teachers (Ponticell, 1995), though it rose ethical and loyalty problems, yet it could explain how good teacher professionalism regarding the attitude towards their colleagues is (Campbell, 1996) and be a way to improve professionalism development process (Hargreaves, 2000). However, during collegial phase, a teacher tended to depend on their colleagues so that less autonomy situation declined their personal professionalism.

The growth of educational needs requires professionalism development, thus professional teachers indicate the birth of a new era of education (Hargreaves, 2000). Based on indicators conceptualized by Hargreaves (2000), we face post-modern phase where teachers are required to possess high flexibility and democratic professionalism which means that teachers need to have many skills and knowledge. This phenomenon leads teachers to be sensitive to stakeholders needs and let them involve in making decision process (Whitty, 2006). On the other hand, professionalism in post-modern phase has reached the diminishing point.

The professionalism of teachers in Indonesia is practically different from the concept. Indonesian government requires tougher education and training for pre-service teachers so that they are able to provide better performance in educating students. Nonetheless, the enhancement of teacher quality is not linear with the supporting infrastructure of educational institutions. In this case, based on the ages of professionalism, we can identify and map the educational evolution in other countries, especially in Indonesia. Therefore, this study will concern in determining the position of educational growth in Indonesia, especially towards civil servant teachers in Tulungagung and Blitar District. The results of this study will imply on the identification and indirectly in assessing how teacher professionalism in Indonesia is.

As the reminder, this study is structured as follows. Section 2 defines the hypotheses tested in this study, while Section 3 describes the sample, model, and variables used. Section 4 encompasses the findings and Section 5 will be for discussion. Finally, conclusion, implications, and suggestions for future research are covered in Section 6. 


\section{Hypotheses Development}

Teacher and Lecturer Act No.14 2005, teachers are considered as the fundamental of professionals so that a teacher needs to possess the required qualification and eventually obtains the consequences as professionalization. Hence, teachers need to maintain and enhance four competences as follows: 1) pedagogical competence; 2) personal competence; 3) social competence; and 4) professional competence. Performance refers to the degree of accomplishment of the task that makes up an employee job. It reflects how well an employee is fulfilling the requirements of the job (Rue \& Byars, 1997), while Bernardian and Russel (1993) stated that performance is defined as the record of outcomes produced or a specific job function or activity during, a specific period.

During pre-professional phase, an education system was simply aimed to deliver a historical knowledge. To be a teacher, we only needed to assign as teaching assistant known as pre-service education for a particular time. Learning how a teacher teaches, what a teacher needs to teach, and how to manage a class were fundamental tasks. Practically, pre-service education which was not concerned to replace a theoretical aspect helped pre-service teachers to understand main tasks of a teacher in teaching an affective aspect related issues, interpersonal relationship rather than a profession which needed specific knowledge and skills (Fajet et al., 2005; Smith \& Lev-Ari, 2006; Cornu \& Ewing, 2008). Thus, hypothesis 1 is stated as:

\section{H1: Pre-professional phase has no positive and significant effect towards a teacher performance}

Educational innovation has been emboldened and has become a major concern in autonomous phase. A teacher was given legal authority in teaching and developing learning process, along with the decision-making process. It was incurred since investment in education has been developed significantly in accordance with demands of knowledge and technology development (Olson, James, \& Lang, 1999; Hargreaves, 2000). As considering how the changes were carried out, the concept was including teacher professionalism and indeed teachers should have authority to improve their professionalism (Sachs, 2015). Therefore, the second hypothesis is stated as:

\section{H2: Autonomous phase positively and significantly influences a teacher performance}

Further, teacher perceptions regarding professionalism have gradually become professional enhancement (Ifanti \& Fotopoulopou, 2011). Teachers are required to enhance their quality in accordance with the development of educational needs. A collegial or a teacher collaboration in developing their professionalism was an effective way to address the challenge of curriculum changes. A collegial interaction significantly motivates the learning process and the teacher professionalism enhancement (Ponticell, 1995). Despite collegiality among teachers could raise ethical and loyalty related problems, yet it can be used to explain teacher professionalism based on how the partner behaves (Campbell, 1996) and is a strategy to heal teacher professional enhancement (Hargreaves, 2000). Nonetheless, in this phase, teacher dependence of each other is significantly high, so that teacher autonomy is decreased and eventually will decline self-quality as a professional that should be inherent in each teacher.

\section{H3: Collegial phase has a negative and significant effect towards teacher performance}

In addition, educational changes and development that require professionalism enhancement and professional teachers indicate the emergence of new educational phase (Hargreaves, 2000). This era, known as post-modern phase, is identical with flexibility and democratic professionalism which mean that a teacher should master multi-skills and knowledge. Teacher professionalism, in advance, needs to fulfill the requirement of current policy to support innovation (Seo, 2016), to fulfill stakeholder's needs and to develop the needs of future, so that it will contribute to enhancing new knowledge (Sachs, 2015). The emergence of teachers to possess democratic professionalism, opened to stakeholder needs, and providing opportunities for decision making related parties is significantly increased (Whitty, 2006). In other words, professionalism, arguably, has been reached the diminishing point and it is likely to be ignored, yet it is not bearable that the discussion of teacher professionalism still becomes a curiosity, since the development of next generation is relied on strategy and mobilization of teachers as known as teacher professionalism (Sachs, 2015; Seo, 2016). Consequently, the last hypothesis is stated as:

\section{H4: Post-modern phase positively and significantly affects teacher performance}

\section{Method}

This study is a perception study where the perception of teachers is recorded using questionnaires for all variables used in this study and quantified using a likert scale, yet we standardize the data obtained (instead of using raw data). We employ 5-1 to scale the questionnaires. Scale 5 is for the most positive response of agreement that the magnitude of responses will be gradually decreased by 1 point and scale 1 is for the most 
negative response of disagreement. Teacher competences based on No.14 Act 2005 about teachers and lecturers by Indonesian Government are the dependent variable, while we employ professionalism phases (Hargreaves, 2000 ) as the independent variable and a teacher tenure as moderating variable as shown in figure 1 . The description of variable used is explained in Appendix.

Sample of this study is 100 high school teachers in Tulungagung and Blitar District and retrieved using proportional sampling method in October-December 2015. We record teacher perception regarding four competences as teacher professionalism and also professionalism phases using questionnaires for each competences and phases. Those questionnaires have been piloted to 30 teachers that have similar characteristics with the sample used to test the validity and reliability of the questionnaires. Based on trials results, we found that all questionnaires are reliable to collect the data for this study (the smallest Cronbach Coefficient Alpha is autonomous questionnaire of 0.7949 and the highest one is pre-professional questionnaire of 0.8929 ). Nonetheless, some questions of the questionnaires need be omitted due to insufficient Pearson Correlation Coefficient (critical $\mathrm{r}$ of 0.349), as follows: pedagogical competence questionnaire (no. 1, 2, 9), social competence questionnaire (no. 8), pre-professional phase questionnaire (no. 2), autonomous professional phase questionnaire (no. 5, 6, 13,14, 16), collegial professional phase (no. 3, 9, 13, 16, 19, 21), and post-professional phase questionnaire (no. 3,11 ).

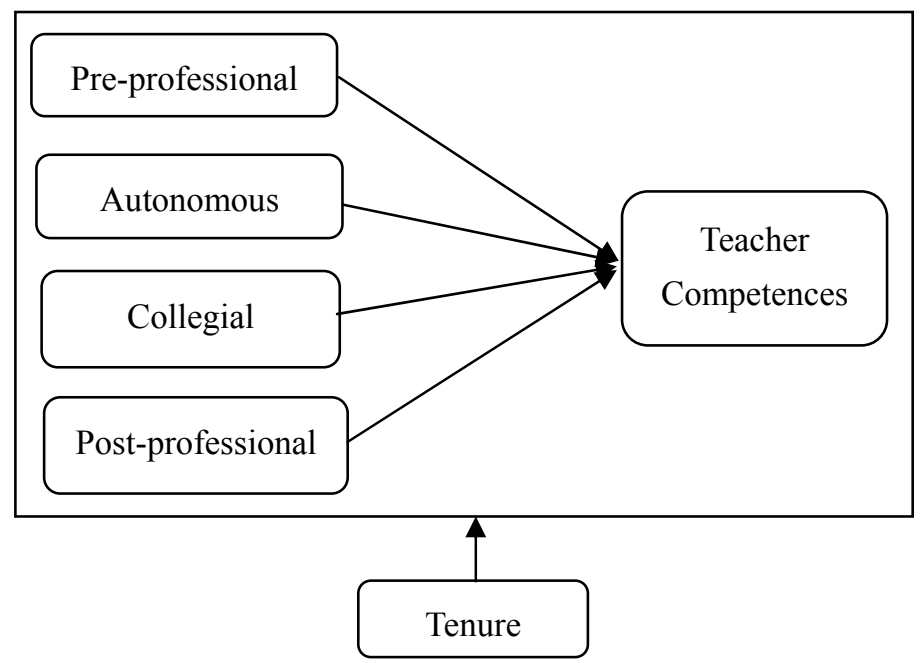

Figure 1. Research design

Note. Figure 1 describes the research framework of this study. We examine the effect of professionalism development phases towards teacher competences. The development phases of professionalism are pre-professional phase, autonomous professional phase, collegial professional phase, and post-professional phase. We measure teacher competences based on pedagogical competence, personal competence, social competence, and professional competence. Additionally, we include Tenure as a proxy of the time that has been dedicated by teachers to moderate the effect of professional phases.

The standardized value of data obtained is analyzed using multiple regression which the model could be conceptualized bellow:

$$
T C=\alpha+\beta_{1} \text { Pre }-\beta_{2} \text { Autonomous }+\beta_{3} \text { Collegial }+\beta_{4} \text { Post }+\beta_{5} \text { Tenure }+\varepsilon
$$

In pre-professional phase (Pre), being a teacher was about being an apprentice for a particular period only to learn how to teach, what to teach, and how to manage a class. However, apprenticeship should not omit other aspects needed in teaching and learning process (i.e. affective aspects, interpersonal skills). Teachers in pre-professional phase appeared to concern about their students more than consequences following their profession. Therefore, we expect a positive sign of pre-professional phase. Autonomous phase (Autonomous) contributed progressive attributes, where an educational innovation was carried on and has become the main contribution on this phase. Investment for education was linear to educational needs of technology development and knowledge. Teachers tried to compete with each other to improve their innovation portfolio. Thus, we expect a positive sign of this phase. 
The concept of professional development became the main margin of collegial phase (Collegial). On this phase, teachers worked collaboratively each other to improve their teaching quality when they faced singularity in the previous phase. Collegial interaction strongly supports the process of professional development and defines personal competence which means that it could raise ethical problems. Yet, a positive sign is expected for this phase. Eventually, education in post-modern or post-professional (Post) phase requires flexibility and democratic professionalism, which means that a teacher needs to possess multi-talents or skills. On the other hand, professionalism has been diminished, yet a positive sign is expected for this phase.

Besides, we also consider how long a teacher has been dedicating his time and effort for his profession. Thus, we employ Tenure as a moderating variable for the primary model. Tenure is positively related to teacher professionalism (Burden, 1982; Christensen et al., 1983; Sikes et al., 1985; Goodson, 1992), the longer a teacher dedicates his time and effort to education, there will be an improvement on his professionalism and professional consequences. Therefore, we expect a positive sign for this phase.

\section{Results}

After standardizing the questionnaire data from 100 observations, we describe the data as shown in Table 1 . Teacher perception regarding professional phases is drawn vary for each phase. Pre-professional phase appears to be perceived lower than other phases, however nowadays teachers tend to appreciate how a teacher was during that phase. It is proven by the minimum data of pre-professional phase is the most negative that the other three professionalism phases. Most of respondents have been devoting in education for 16 years.

Table 1. Descriptive statistics

\begin{tabular}{ccccccc}
\hline Variable & Minimum & Q1 & Median & Q3 & Maximum & Std \\
\hline Pre & -47.4482 & -3.0282 & 1.6088 & 6.0345 & 21.2597 & 10.7507 \\
Autonomous & -13.6090 & -4.1010 & 0.6684 & 2.9128 & 13.4621 & 6.0564 \\
Collegial & -22.0324 & -6.2399 & 0.4526 & 7.3386 & 23.7988 & 10.0451 \\
Post & -17.6989 & -4.4812 & -2.0079 & 5.1851 & 22.1142 & 8.1345 \\
Tenure & 3.0000 & 10.0000 & 13.0000 & 24.0000 & 32.0000 & 8.0942 \\
Pedagogical Competence & -22.3279 & -6.2857 & 0.3227 & 5.7418 & 22.9666 & 8.9128 \\
Personal Competence & -16.1194 & -4.4009 & 0.9177 & 5.0468 & 10.1791 & 6.4701 \\
Social Competence & -11.0301 & -3.6577 & -1.9891 & 3.8721 & 13.0802 & 5.9206 \\
Professional Competence & -13.9362 & -4.4623 & -1.2631 & 4.6836 & 13.8907 & 6.0702 \\
\hline
\end{tabular}

Note. Table 1 provides statistics for variables used in this study. This study uses 100 observations obtained in October-December 2015. The variables used in this study are explained in Appendix. The dependent variable of this study is teacher competences (TC) constructed from pedagogical competence, personal competence, social competence, and professional competence.

Table 2 provides the regression results of teacher competences as a proxy of teacher professionalism (dependent variable), professionalism phases (independent variables) and tenure as a moderating variable. Classical assumptions of regression model have been performed which include normality test, autocorrelation test, heteroscedasticity test, and multicollinearity test. Kolmogorov-Smirnov test results in a significant coefficient at $10 \%$ level ( $\mathrm{p}$-value of 0.087), Cramer-von Mises and Anderson-Darling are significant as well (p-value of 0.024 and 0.014 respectively), thus the data of this study is normal. The value of Durbin-Watson, 1.983, falls between 1.5 and 2.5, which means that the model used is free from autocorrelation problem. Additionally, the model used is free from heteroskedasticity problem (chi-square of 19.90 with p-value of $0.4644>0.05$ ). Finally, the model employed in this study does not have multicollinearity problem since Eigenvalue of each independent variables is less than 5 (Pre of 2.2027, Autonomous of 1.0349, Collegial of 1.0090, Post of 0.4713, and Tenure of 0.2820). 
Table 2. Regression result

\begin{tabular}{lcccc}
\hline \multirow{2}{*}{ Model } & \multicolumn{2}{c}{ Unstandardized Coefficients } & \multirow{2}{*}{$\mathrm{t}$} & Sig. \\
\cline { 2 - 3 } & $\mathrm{B}$ & Std. Error & & \\
\hline (Constant) & $-4.6201 * *$ & 2.0361 & -2.27 & 0.0255 \\
Pre & $0.1682 *$ & 0.0934 & 1.80 & 0.0749 \\
Autonomous & 0.2327 & 0.2669 & 0.87 & 0.3855 \\
Collegial & $1.9172 * * *$ & 0.1937 & 9.90 & $<.0001$ \\
Post & $0.9258 * * *$ & 0.1873 & 4.94 & $<.0001$ \\
Tenure & $0.2904 * *$ & 0.1141 & 2.54 & 0.0126 \\
\hline Adj $\mathrm{R}^{2}$ & 0.8203 & & & \\
\hline
\end{tabular}

Note. Regression of teacher competences and professional phases:

$$
T C=\alpha+\beta_{1} \text { Pre }-\beta_{2} \text { Autonomous }+\beta_{3} \text { Collegial }+\beta_{4} \text { Post }+\beta_{5} \text { Tenure }+\varepsilon
$$

This table presents the regression result of teacher professionalism with teacher competences as a proxy and each professionalism phases by Hargreaves (2000). The results are significant at level 1\%, 5\%, and $10 \%$ indicated by $* * *, * *$, and * respectively. Variables are described in Appendix.

Based on the result above, all coefficients are as expected and significant, except for autonomous professional phase. The pattern of teacher professionalism in Indonesia is more likely identified in collegial professional phase. It is shown in Table 1 that collegial professional phase has the highest effect and significance over other phases. Teacher professionalism appeared to be the main concern in pre-professional phase, since it has a positive and significant coefficient (Pre, $\beta$ of 0.1682 with p-value of 0.0749 ). Although being a teacher was simply being an apprentice to learn how to teach and manage a class, however a teacher on this phase firmly concerned on teaching quality. Adversely, we could not found that teacher professionalism during autonomous professional phase was more developed due to the insignificant result of autonomous coefficient though the sign is as expected (Autonomous, $\beta$ of 0.2327 with p-value of 0.3855 ).

Professional development of collegial phase seemed to be an important program, since teachers have eliminated their singularity and broaden their horizon by sharing knowledge and skills with their colleagues. It is shown by the result of collegial phase which has a positive and significant effect (Collegial, $\beta$ of 1.9172 with p-value of 0.0001). This result is slightly different from post-professional phase. A teacher has become more professional day by day and it has been improved continuously, thus, post-professional phase has a positive and significant effect as expected (Post, $\beta$ of 0.9258 with p-value of 0.0001 ). Besides, we include Tenure as moderating variable to bridge the influence of teachers' perception on professionalism phases towards teacher professionalism, is positively and significantly related to teacher competences (Tenure, $\beta$ of 0.2904 with p-value of $0.0126<0.05$ ). Tenure boosts the effect of teachers' perception of professional phases towards teacher professionalism and raises the significance (the result is un-tabulated).

The correlation among variables employed in this study is explained in Table 3. Referring to Spearman coefficient, all independent variables are positively and significantly related to teacher competences, while pre-professional phase could not be significantly captured by teachers' perception nowadays (Pre, Pearson coefficient, $r$ of 0.0672 with $p$-value of 0.5068 ). This result is similar to the remaining independent variables. Pre-professional phase is not significantly related to other independent variables.

Table 3. Correlation coefficient

\begin{tabular}{llccccccccc}
\hline Variable & $(1)$ & $(2)$ & $(3)$ & $(4)$ & $(5)$ & $(6)$ & $(7)$ & $(8)$ & $(9)$ \\
\hline \multirow{2}{*}{ TC (1) } & 1 & 0.0672 & 0.6004 & 0.8660 & 0.7667 & 0.8456 & 0.8046 & 0.8349 & 0.8636 \\
& & $(0.5068)$ & $(0.0001)$ & $(0.0001)$ & $(0.0001)$ & $(0.0001)$ & $(0.0001)$ & $(0.0001)$ & $(0.0001)$ \\
Pre (2) & 0.2298 & & -0.0105 & -0.0706 & 0.1080 & 0.0651 & 0.03826 & 0.05877 & 0.0616 \\
& $(0.0215)$ & & $(0.9175)$ & $(0.4855)$ & $(0.2847)$ & $(0.5198)$ & $(0.7055)$ & $(0.5614)$ & $(0.5428)$ \\
Autonomous (3) & 0.5845 & 0.0786 & & 0.6057 & 0.5132 & 0.5245 & 0.4099 & 0.5235 & 0.5542 \\
& $(0.0001)$ & $(0.4372)$ & & $(0.0001)$ & $(0.0001)$ & $(0.0001)$ & $(0.0001)$ & $(0.0001)$ & $(0.0001)$ \\
Collegial (4) & 0.8302 & 0.1681 & 0.6022 & & 0.6805 & 0.7946 & 0.6805 & 0.7212 & 0.6868 \\
& $(0.0001)$ & $(0.0946)$ & $(0.0001)$ & & $(0.0001)$ & $(0.0001)$ & $(0.0001)$ & $(0.0001)$ & $(0.0001)$ \\
\hline
\end{tabular}




\begin{tabular}{lllllllllll}
\hline Post (5) & 0.6801 & 0.3561 & 0.4987 & 0.6134 & & 0.6694 & 0.4956 & 0.6378 & 0.7665 \\
& $(0.0001)$ & $(0.0003)$ & $(0.0001)$ & $(0.0001)$ & & $(0.0001)$ & $(0.0001)$ & $(0.0001)$ & $(0.0001)$ \\
Pedagogical Competence (6) & 0.8042 & 0.2253 & 0.5137 & 0.7656 & 0.5928 & & 0.4959 & 0.6116 & 0.6477 \\
& $(0.0001)$ & $(0.0242)$ & $(0.0001)$ & $(0.0001)$ & $(0.0001)$ & & $(0.0001)$ & $(0.0001)$ & $(0.0001)$ \\
& 0.8127 & 0.1347 & 0.4332 & 0.6689 & 0.4835 & 0.4595 & & 0.5974 & 0.6251 \\
Personal Competence (7) & $(0.0001)$ & $(0.1817)$ & $(0.0001)$ & $(0.0001)$ & $(0.0001)$ & $(0.0001)$ & & $(0.0001)$ & $(0.0001)$ \\
& 0.8126 & 0.2144 & 0.4968 & 0.6923 & 0.5916 & 0.5655 & 0.6188 & & 0.6414 \\
Social Competence (8) & $(0.0001)$ & $(0.0322)$ & $(0.0001)$ & $(0.0001)$ & $(0.0001)$ & $(0.0001)$ & $(0.0001)$ & & $(0.0001)$ \\
& 0.8336 & 0.2155 & 0.5607 & 0.6341 & 0.7157 & 0.5987 & 0.6365 & 0.5756 & 1 \\
Professional Competence (9) & $(0.0001)$ & $(0.0313)$ & $(0.0001)$ & $(0.0001)$ & $(0.0001)$ & $(0.0001)$ & $(0.0001)$ & $(0.0001)$ &
\end{tabular}

Note. This table provides correlation matrix for 100 observations of high school teachers in Tulungagung and Blitar District. The upper diagonal is for Pearson coefficients and the lower diagonal is for Spearman coefficients. All coefficients are significant at the level 1\%,5\%, and 10\% except for those in italic. Variable are described in Appendix

\section{Discussion}

Teacher professionalism has been extensively concerned as educational urgency. Teacher professionalism is virtually improved along the growth of educational needs. Hargreaves (2000) has fragmented teacher professionalism based on the term of the time flow and consequences following. The first era identified was pre-professional phase, when a teacher seemingly devoted herself at any costs to pedagogically in-class teaching and learning though it was simply through pre-service education. It is proven by the highest and most significant correlation of pre-professional phase towards pedagogical competence (Pre, $r$ of 0.2253 with p-value of 0.0242) among other competences, while it is also positively and significantly influences teacher professionalism. Therefore, the result of this study supports that teachers with pre-service education possess higher professionalism than those without pre-service education.

Teachers in pre-professional phase were highly demanded and well designated though the cultural importance of historical knowledge was rooted (Hargreaves, 2000). Nonetheless, teachers are considered as enthusiastic people that put all their best into teaching and in-class learning process. Pre-service education was the only way to create teachers on that phase which gave practical learning process by assessing what a teacher did in class, how to teach and how to manage the class. Indeed, it was not the proper way to be a teacher, since pre-service education was not to replace theoretical learning process which would help to understand the main role of a teacher on affectively teaching process and interpersonal skill as a complement of professional skills and knowledge (Fajet et al., 2005; Smith \& Lev-Ari, 2006; Cornu \& Ewing, 2008). Nonetheless, the only concern of teachers on teaching and learning process appeared to be the excellence of being a teacher (Hargreaves, 2000).

Further, we could not support that teacher professionalism was well improved during autonomous phase (Autonomous, $\beta$ of 0.2327 with p-value of 0.3855 ). The following consequences of pre-professional phase which limited teachers from outside class querying were creating teachers as isolated people. Moreover, education was not stuck at one point when the challenges have been overcome. Education was dynamic along the growth of educational needs since it was discovered even when it has reached the diminishing point.

Teaching professionalism was grown during autonomous phase following the improvement of the status and standing of teachers along with the increase of investment in education. Teachers put their best efforts in improving their skills and knowledge by exploring in-class pedagogic teaching and learning process since it was highly demanded on this phase (Olson, James, \& Lang, 1999; Hargreaves, 2000), which was also driven by the continuation of improving qualification, namely professionalization in teaching or an extending accreditation (Hargreaves, 2000). However, teachers appeared to compete each other, they did not work together nor share their skills and knowledge to develop their qualification so that what they have done was limited to individual horizon of witting (singularity) which was not as broad as when they got to work collaboratively.

The following era, collegial professional phase, was far different from the previous phases. Teacher professionalism was well developed during this phase, so did teachers' perception regarding professionalism development (Ifanti \& Fotopoulopou, 2011). It does make sense when the diversity of educational needs 
constantly become broader, teaching methods and practices could not be considered as simple as managing classes. Therefore, teachers were required to be more innovative and to improve their quality not only on pedagogical aspect but also affective aspect and interpersonal skill that could be fulfilled in collegial professional phase. Hence, we support that teacher professionalism is increasingly developed through collaborative works (Collegial, $\beta$ of 1.9172 with $p$-value of 0.0001 ).

Collegial or collaborative works among teachers, in professional development, has been an effective strategy in facing rapid educational needs growth. However, it was not only the growth of educational needs, Hargreaves (2000) explored many factors involved in encouraging collaborative works, as follows: a) the rapid change of knowledge and of what teachers are expected to teach; b) the expansion of teaching and learning methods; c) the increase of the social work responsibilities; d) the complexity of education needs due to the development of technology and additional knowledge; e) the cultural limits in improving in-class teaching; f) additional needs of students; g) the change of school management; and h) the success implementation of collaborative works.

Based on explanation above, professional development is not only well developed by the knowledge transfer of experts, but also by collegial interaction between teachers and their colleagues, principles, students, stakeholders, and embedded among those parties, since the support and involvement of those around a teacher might be the reasons of successful collaborative works (Little, 1993). This condition was explained by Barber (2004) as an indicator of informed professionalism where teachers possess appropriate knowledge and skills to develop what they intend to do based on the growth of educational needs. We can argue that teachers have high possibilities in improving their quality on their own circumstances.

Teacher professionalism in post-modern phase is increasingly well developed and even, it has been reached the point where professionalism does not need to get improved (Hargreaves, 2000). On this phase, teachers are expected to be able in accommodating stakeholders' interests and letting them get involved in making a decision. This condition drives teachers to be flexible and democratic in fulfilling their roles as an educator. This result similar to Sachs (2015) that teacher professionalism has not moved on from autonomy phase to develop new knowledge by improving teacher efficacy (Seo, 2016). However, it should be derived to fulfill government policy and the future needs of stakeholder (Sachs, 2015). In regard to post-modern or post-professional phase, the result of this study supports that the more democratic teachers in carrying out their duties, the higher the professionalism they possess. Further, Hargreaves (2000) explained that the pattern of teacher professionalism in post-modern phase is appeared to be similarly an iteration of pre-professional phase. It is proved by the significance of correlation between pre-professional phase and post-professional phase is higher than the significance of correlation between pre-professional phase and other phases. Thus, it indicates that teacher professionalism of post-professional phase has been reached the diminishing point so that it turns to the initial pattern of professionalism.

\section{Conclusion}

The rationale for studying professionalism phases by Hargreaves (2000) is to understand the pattern of teacher professionalism which is vary on one phase to other phases. Using 100 observations, we examine whether teacher's perception is affected by the development of teacher professionalism time to time. We observe teacher's perception by using questionnaire of professionalism phases and teacher competences. The results of this study indicate that every phase captured the right pattern of professionalism development. Pre-professional phase is identical with pre-service education that needed to be passed when someone wanted to be a teacher, thus pre-service education was probably a measure of teacher competence and professionalism on that phase. The following effect of this phase along with the growth of educational needs, teachers in autonomous phase appeared to face singularity since pedagogical competence seemed to be more important than other competences.

Accordingly, diversity of educational needs has been broadened phase to phase, yet teacher professionalism got improved and well developed to overcome and fulfilled this challenges. In addition, indeed the pattern of teacher professionalism for each phase still need to be deeply observed and adjusted to the cultural importance and circumstance of Indonesia, especially regarding autonomous professional phase which has insignificant result in this study. In the other hand, there could be other factors that may influence the magnitude of teacher professionalism. Lastly, it is expected to involve more respondents and to measure teacher competences using assessment tool so that the pattern captured could be drawn correctly.

\section{References}

Barber, M. (2004). The virtue of accountability: System redesign, inspection, and incentives in the era of informed professionalism. The Journal of Education, 185(1), 7-38. 
Bernaddin, J. H., \& Russel, E. A. (1993). Human Resource Management. Singapore: McGraw Hill Inc.

Burden, P. R. (1982). Developmental Supervision: Reducing Teacher Stress at Different Career Stages. Paper presented at the Association of Teacher Educators, Phoenix, Arizona, ERIC Microfiche ED, pp. 218-267.

Campbell, E. (1996). Ethical Implications of Collegial Loyalty as One View of Teacher Professionalism. Teachers and Teaching: Theory and Practice, 2(2), 191-208. http://dx.doi.org/10.1080/1354060960020203

Christensen, J., Burke, P. J., Fessler, R., \& Hagstrom, D. (1983). Stages of Teacher's Careers: Implications for Staff Development. ERIC Clearing House on Teacher Education, One Dupont Circle, Suite 610, Washington, DC 20036, Ed. 227(54), 1-34.

Cornu, R. L., \& Ewing, R. (2008). Reconceptualising Professional Experiences in Pre-service Teacher Education: Reconstructing the Past to Embrace the Future. Teaching and Teacher Education, 24(7), 1799-1812. http://dx.doi.org/10.1016/j.tate.2008.02.008

Cuban, L. (1984). How Teachers Taught: Constancy and Change in American Classroom, 1890-1980. Research on Monograph Series, published online by ERIC (pp. 1-306). http://dx.doi.org/10.2307/3323864

Curtis, B. (1988). Building the Educational State: Canada West, 1836-1871 (p. 450). Falmer Press and Alhouse Press, Sussex, England, and London, Ontario. http://dx.doi.org/10.7202/304684ar

Dessler, G. (2009). Fundamentals of Human Resource Management. London: Pearson Education.

Fajet, W., Bello, M., Leftwich, S. A., Mesler, J. L., \& Shaver, A. N. (2005). Pre-Service Teachers' Perceptions in Beginning Education Classes. Teaching and Teacher Education, 21(6), 717-727. http://dx.doi.org/10.1016/j.tate.2005.05.002

Goodson, I. F. (1992). Studying Teachers' Lives (pp. 1-272). Routledge, London. http://dx.doi.org/10.4324/9780203415177

Hargreaves, A. (2000). Contrived Collegiality: The Micropolitics of Teacher Collaboration. Educational Psychology, 3(63), 1480-1503.

Hargreaves, A. (2000). Four Ages of Professionalism and Professional Learning. Teachers and Teaching: History and Practice, 6(2), 151182. http://dx.doi.org/10.1080/713698714

Ifanti, A. A., \& Fotopoulopou, V. S. (2011). Teachers' Perceptions of Profesionalism and Professional Development: A Case Study in Greece. World Journal of Education, 1(1), 40-51. http://dx.doi.org/10.5430/wje.v1n1p40

Little, J. W. (1993). Teachers' Professional Development in a Climate of Educational Reform. Educational Evaluation and Policy Analysis, 15(2), 129-151. http://dx.doi.org/10.3102/01623737015002129

Olson, J., James, E., \& Lang, M. (1999). Changing the Subject: The Challenge of Innovation to Teacher Professionalism in OECD Countries. Journal of Curriculum Studies, 31(1), 69-82. http://dx.doi.org/10.1080/002202799183304

Ponticell, J. A. (1995). Promoting teacher professionalism through collegiality. Journal of Staff Development, 16(3), p. 13-18.

Rue, L., \& Byars, L. (1997). Management Skill and Application (8thed.). Singapore: MacGraw Hill Inc.

Sachs, J. (2015). Teacher professionalism: why are we still talking about it? Teachers and Teaching, 22(4), 413-425. http://dx.doi.org/10.1080/13540602.2015.1082732

Seo, S. J. (2016). Teaching Efficacy Belief as a New Paradigm for Teacher Career Development and Professionalism in Korea. In Asia-Pacific Perspectives on Teacher Self-Efficacy (pp. 53-69). Sense Publishers. http://dx.doi.org/10.1007/978-94-6300-521-0_4

Sikes, P. J., Measor, L., \& Woods, P. (1985). Teacher Careers: Crisis and Continuities. London: Falmer Press.

Smith, K., \& Lev-Ari, L. (2006). The Place of the Practicum in Pre-service Teacher Education: The Voice of the

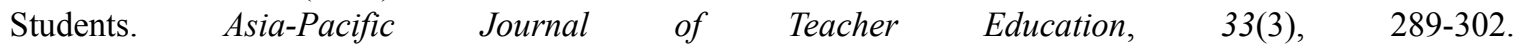
http://dx.doi.org/10.1080/13598660500286333

Whitty, G. (2006). Teacher Professionalism in a New Era. General Teaching Council for Northern Ireland Annual Lecture. 


\section{Appendix}

\section{Variables Description}

\begin{tabular}{|c|c|c|}
\hline Variable & Indicator & Questionnaire \\
\hline \multicolumn{3}{|c|}{ Teacher Competences } \\
\hline $\begin{array}{l}\text { Pedagogical } \\
\text { Competence }\end{array}$ & $\begin{array}{l}\text { - Possessing good understanding regarding students' } \\
\text { needs } \\
\text { - Lesson planning and implementation } \\
\text { Evaluation skill on learning achievement } \\
\text { Developing and actualizing students' interest and skills }\end{array}$ & $\begin{array}{l}\text { Pedagogical Competence } \\
\text { Questionnaire } \\
\text { \# 3-8, 10-17 }\end{array}$ \\
\hline $\begin{array}{l}\text { Personal } \\
\text { Competence }\end{array}$ & $\begin{array}{l}\text { - Firm } \\
\text { - Stable } \\
\text { - Mature } \\
\text { - Sensible } \\
\text { - Wise } \\
\text { - Being a good example } \\
\text { - Fine attitude }\end{array}$ & $\begin{array}{l}\text { Personal Competence } \\
\text { Questionnaire } \\
\# 1-11\end{array}$ \\
\hline $\begin{array}{l}\text { Social } \\
\text { Competence }\end{array}$ & $\begin{array}{l}\text { - Teacher competence in blending with society, where a } \\
\text { teacher need to have a good and an effective } \\
\text { communication skill. }\end{array}$ & $\begin{array}{l}\text { Social Competence } \\
\text { Questionnaire } \\
\# 1-7,9,10\end{array}$ \\
\hline $\begin{array}{l}\text { Professional } \\
\text { Competence }\end{array}$ & $\begin{array}{l}\text { - Possessing a great knowledge and skill to educate and } \\
\text { guide students in passing the National Education } \\
\text { Standards }\end{array}$ & $\begin{array}{l}\text { Professional Competence } \\
\text { Questionnaire } \\
\# 1-10\end{array}$ \\
\hline
\end{tabular}

Professionalism Phases

\begin{tabular}{|c|c|c|c|}
\hline $\begin{array}{l}\text { Pre-professional } \\
\text { Phase }\end{array}$ & $\begin{array}{l}\text { - Mass Education } \\
\text { - Limited textbooks and learning resources } \\
\text { - A class system was started to employ } \\
\text { - A teacher was the main controller of a class } \\
\text { - Teaching methods used were discourse, assignment } \\
\text { (repeating the discourse) with taking a note, question } \\
\text { and answer session } \\
\text { - Students were motivated to compete in class } \\
\text { - Teaching process for all classes were equal } \\
\text { - Teaching materials were historical knowledge } \\
\text { - Teaching was considered as simply as managing a class } \\
\text { - Pedagogical aspect was the main concern of teaching } \\
\text { education which was limited to apprenticeship. }\end{array}$ & $\begin{array}{l}\text { Pre-professional } \\
\text { Questionnaire } \\
\# 1,3-17\end{array}$ & Phase \\
\hline $\begin{array}{l}\text { Autonomous } \\
\text { Professional } \\
\text { Phase }\end{array}$ & $\begin{array}{l}\text { - The status and standing of teachers were significantly } \\
\text { increased } \\
\text { - Education for teacher was not limited to be an } \\
\text { apprenticeship, but it has been carried on higher school } \\
\text { education level } \\
\text { - Teachers got full autonomy for their classes and } \\
\text { students } \\
\text { - Commitment and investment in developing technology } \\
\text { and innovation in education are from government and }\end{array}$ & $\begin{array}{l}\text { Autonomous } \\
\text { Professional } \\
\text { Questionnaire } \\
\# 1-4,7-12,15\end{array}$ & Phase \\
\hline
\end{tabular}


private institutions.

- Being professional and holding full autonomy could not be separated.

- Professionalization was growing along the development of teacher professionalism

- Teaching was losing the righteous due to the contrary of educational idealism.

- Student-centered learning, deschooling and freeschooling, was broadly carried on.

- Singularity has become the main problem faced

- There was less assessment and feedback on teachers' performance

\begin{tabular}{|c|c|c|}
\hline $\begin{array}{l}\text { Collegial } \\
\text { Profession } \\
\text { Phase }\end{array}$ & $\begin{array}{l}\text { - Teachers started to work collaboratively } \\
\text { - Teaching materials were expanded rapidly } \\
\text { - The development of knowledge and teaching methods } \\
\text { were significant } \\
\text { - Social responsibilities were partly as teaching } \\
\text { responsibilities } \\
\text { - Special educational needs were included in-class } \\
\text { teaching and learning } \\
\text { - Multicultural challenges } \\
\text { - Teachers are expected to have discussion session with } \\
\text { students to discuss both learning difficulties and } \\
\text { students' personal problems. } \\
\text { - The change of management and leadership system } \\
\text { - Teachers community has been developed } \\
\text { - Collaborative works of teachers gave positive effects to } \\
\text { student learning achievement }\end{array}$ & $\begin{array}{l}\text { Collegial Professional } \\
\text { Phase Questionnaire } \\
\# 1,2,4-8,10-12,14, \\
15,17,18,20\end{array}$ \\
\hline $\begin{array}{l}\text { Post-professional } \\
\text { Phase }\end{array}$ & $\begin{array}{l}\text { - The concept of professionalism becomes flexible and } \\
\text { democratic } \\
\text { - Teacher professionalism is slightly declined and } \\
\text { abandoned } \\
\text { - Professionalization has been a firm motivation of } \\
\text { teachers to improve their qualification } \\
\text { - Collaborative works are not limited to same institution } \\
\text { colleagues, but also to outside colleagues } \\
\text { - Teachers need to improve their knowledge and skills } \\
\text { along with high diversity of educational needs }\end{array}$ & $\begin{array}{l}\text { Post-professional Phase } \\
\text { Questionnaire } \\
\# 1,2,4-10,12-15\end{array}$ \\
\hline
\end{tabular}

\section{Copyrights}

Copyright for this article is retained by the author(s), with first publication rights granted to the journal.

This is an open-access article distributed under the terms and conditions of the Creative Commons Attribution license (http://creativecommons.org/licenses/by/4.0/). 